\title{
Crossing the Past Political Boundary: Teacher Professional Learning in a South African Reform Context
}

\author{
Simangele Mkhwanazi
}

Department of Educational Leadership and Management, UNISA

Email:mkhwats@unisa.ac.za

\section{Doi:10.5901/mjss.2014.v5n10p425}

\begin{abstract}
A promising shift in the interventions that help promote teachers' knowledge and skills in the South African current reform era is highly evident. Yet, a large part of research suggests that effective teacher change in knowledge and learning remains an elusive target for some teachers in this context. This paper reviews and analyses how teacher professional learning and knowledge have been conceptualised and studied since the inception of educational reforms in post-apartheid South Africa. Using the integrative synthesis, this paper demonstrates that the scholarship in this field recognise that it is not just the existence of the professional learning activities that affect teachers' practices but the "what" and "how" of these professional learning activities. This paper argues that further complex conceptualisation of teacher professional learning that focus on how teachers learn from their working environments and the conditions that support and promote learning in these environments carries implications for the design of the professional learning opportunities that promise effective change in teacher learning.
\end{abstract}

Keywords: teacher professional learning, professional development, education reform, teacher change, situative perspective.

\section{Introduction}

Education reforms that were initiated after 1994 in South Africa elicited an urgent need to change the existing teacher profession and develop one that is relevant for a democratic South Africa in the 21st century (Department of Education, 2006: 4). Stated simply, teachers needed to develop specific new professional knowledge and skills to be able to fit within a new reform context. To achieve that, they needed to be equipped with competences and skills that would be acquired through engaging in professional development (PD) programmes. However, a closer examination of the conception of teacher professional learning in this context warrants attention. This is stimulated by the fact that, despite numerous interventions to enhance teachers' professional learning in this context, the change in some of the teachers' knowledge and teaching approach that was envisaged remains yet to be seen (Mulaudzi, 2009; Smit; 2001; Botha, 2000; Jita \& Ndlalane, 2009; Bantwini, 2010).

Teacher professional learning refers to the changes in how teachers think, what they know and how they approach their teaching (Knapp, 2003). It is acknowledged as the process that evolves after engaging in the event of professional development. This process is initiated when the teacher enters the teacher training phase and continues throughout the teachers' working experience. The kinds of teacher knowledge that are developed in these phases focus on what teachers need to know and how they learn to teach that, what they actually know and how they teach. In short, the nature of teachers' professional learning is disseminated in that it encompasses different forms of learning opportunities that occur in both formal and informal venues.

It is my view that education leaders, scholars, service providers and policymakers in South Africa, pressured by the demands of education reforms, focused more on the promotion of effective professional development activities at the expense of the process of teacher professional learning itself. Furthermore, most of the teacher professional development activities fail to address teachers' subject matter knowledge and their instructional practices (Ndlalane, 2006). Even though teachers engage in an array of professional learning opportunities, these opportunities still seem to have less impact on their professional learning. It is my view that the conceptualisations of professional learning in this context are missing some elements and therefore, needs further review. When the education reforms were initiated in South Africa, much of the literature on this conception focused on the types of the professional development programs that would supposedly lead to effective professional learning of teachers (Onwu \& Mogari, 2004; Kriek \& Grayson, 2009). Less was said on what and how teachers learn in these professional learning opportunities. Much less was said about learning in their work environments and the conditions that enhance this learning. It is only in recent literature that indications on how 
teachers acquire learning through their work contexts are seen (Jita \& Ndlalane, 2009; Bryan, 2011; Steyn, 2013).

The purpose of this integrative synthesis is to examine how the existing literature on teacher professional learning and professional development in the South African context conceptualises the professional learning of in-service teachers since the beginning of the education reforms from 1994 up to the present. Teacher professional development became necessary in the light of curriculum changes during this phase (1994 - until present). It was inevitable for teachers to change their existing professional knowledge and skills to be able to produce learners that would fit into this transformed society (Dept of Education, 2002). Consequently, teacher professional learning has, since then, received much attention. In the light of this, this paper aims to explore how the literature makes a distinction between teacher professional development and teacher professional learning. The paper also looks at how the literature on teacher professional learning has evolved during this era. To do this, I bring together the literature on the conceptions of teacher professional learning, professional learning opportunities, and professional development. By doing that, I hope to contribute towards the existing body of knowledge on understanding these concepts and how it influence or fail to influence teacher practice in South Africa.

The synthesis starts with a brief discussion of the situative perspective which frames the ideas of knowing and learning that teachers acquire from the contexts in which they undertake their learning. Following that, the methodology to be used to review literature on this concept of teacher professional learning will be discussed. The next sections focus their discussion on the themes that attempt to shed light on this concept of teacher professional learning as identified in the literature. That includes the general overview of teacher professional learning and professional development, what the literature says about professional development and professional learning in this context; professional learning opportunities and how teachers learn from their environments. Finally, the review considers what the conceptualisations above might suggest about teacher professional learning opportunities that could bring about effective teacher change to all teachers in the reform context.

\section{Theoretical Framework}

The constant struggle of the researchers to get a hold on the effectiveness of teacher professional development that sometimes fail to bring about changes on teachers is a driving force behind this review. Knight, 2002:2, as cited by Bantwini (2011) could not describe this struggle any better as he states that the issue of teacher professional development is a never-ending story that is like a "religious struggle in an escape of sin". In constructing this synthesis, I support a shift in thinking about teacher professional learning that indicates a move from teacher learning as an individual practice to that of collaborative nature (Steyn, 2013). The current paradigm shift shows that effective professional learning that has been proven to elicit changes in teachers' practices (Garet, et al., 2001) takes into account the contexts in which teachers learn while they interact with others on practice-based issues (Lave \& Wenger, 1991; Borko \& Putnam, 2000; Borko, 2004; Eraut, 2007). This is the lens that I use to explore the scholarly works on professional learning in South Africa since the inception of education reforms in this context.

To synthesise the relevant literature, I find the situative perspective to be useful. The situative perspective encompasses notions about the nature of knowledge and learning (Putnam \& Borko, 2000). It emphasises the contexts in which teachers interact as sites where learning takes place. According to this perspective, teacher professional learning is known as "a process of increasing participation in the practice of teaching, and through this participation, a process of becoming knowledgeable in and about teaching" (Adler, 2000:37). Stated another way, the situative perspective tries to redefine the relationship between what teachers learn and the settings in which they learn. Thus, learning for teachers, occurs in some aspects of their teaching practices such as their own classrooms, schools and in their professional learning communities. In other words, the situative perspective emphasises the importance of creating the opportunities for teachers to engage with their colleagues in their contexts to improve their practices. This perspective was initially recognised in the field of educational psychology and it shares some principles with various disciplines such as anthropology, sociolinguistics and psychology.

I draw from the three conceptual themes that are crucial to the situative perspective as illustrated by Putnam \& Borko (2000), to look at how other scholars theorise how teachers learn from various teacher professional learning opportunities. These three themes point to these ideas of knowing and learning as (1) situated in particular physical and social contexts; (2) social in nature and (3) distributed across the individual, other persons and across other tools. Following is the brief exposition of these themes of knowing and learning as: 


\subsection{Situated in particular physical and social contexts}

According to this theme learning cannot be separated from the physical and social contexts. How a person learns a set of knowledge and skills and the contexts in which they learn, determines their nature of learning. The theme draws our attention to the creation of authentic activities in the learning contexts. Authentic activities refer to similar activities that teachers teach in their real classrooms. In other words, if activities done in a particular learning context do not match what actual teachers do in their classrooms, then they fail to impact on the individual's learning. Through this theme, I examine the literature on teacher learning to determine how scholars talk about teachers' experiences in their professional learning opportunities and working contexts to understand how those experiences stimulated teacher learning.

\subsection{Situated as social}

Whilst acknowledging that learning can be an individual experience, the situative perspective emphasises collective learning. This perspective points out that learning takes place through interaction with other people. Through the social contact with other people, the individual acquire knowledge and skills that they use to enhance their practice. The current trend of professional development models that emphasise professional learning communities as most likely to change teacher practices in reform contexts, draws on the ideas of this theme.

\subsection{Situated as distributed}

This theme considers the distribution of knowledge and learning across the people and various cognition tools. These days the use of tools such as computer-based plans and online forums support teachers in their work. These tools also make it possible for teachers to access information from their colleagues outside their contexts and in that way, learn from them. For example, teachers could use video clips of their classroom teaching in any professional learning setting to reflect on their practice. However, in order to prepare teachers to participate successfully in their practice, their learning must achieve a better balance between activities that incorporate ideas of distributed cognition and those that stress only individual competence.

I use this situative perspective as a lens to view the literature on the conception of teacher professional learning in a South African reform context. Previous literature on this conception often regarded professional learning as separate from the context in which it is to be used (Steyn, 2013). The situative perspective emphasises the context in which knowledge is situated, and thus provide justification for the fact that teacher professional learning should be based in their teaching practice.

\section{Methodology}

The initial conceptual framing of this notion of teacher professional learning in the South African reform context focused on understanding the professional development opportunities that supposedly contribute towards teachers' changes in their practices. Later in this reform era, scholarly works on this topic start to recognise the real worlds of teachers' experiences and how they learn from these worlds. This review, therefore, does not aim to repeat that action of discussing professional development activities that promote the growth of teachers' knowledge and skills. Instead, it aims to explore how the theorisation of teacher professional learning in South Africa has contributed towards the understanding of teachers' changes in their practices or lack thereof. It will do that by attempting to assemble theoretical and empirical works that consider the contexts and the "how" of teacher learning.

To conduct the literature search, the databases (e.g. Web of Science, ProQuest) were used to find the abstracts of research studies on professional development or professional learning in South Africa. Google Scholar was also visited and keywords such as "teacher learning", "professional learning", "professional learning communities" and "professional development" in South Africa to identify additional articles were used. A growing number of empirical studies that connect the professional learning opportunities and the changes in the knowledge and practices of teachers in the South African context were also consulted. A separate body of recent literature that focuses on teachers' work environments to improve their learning was also reviewed. Also, the relevant theoretical and empirical scholarship that illuminates the impact of professional learning opportunities on teacher professional learning from scholars around the world was also consulted.

This synthesis organises what the literature have to say about professional development and its connection to teacher professional learning. It also looks at how the literature considers the context in which teacher professional learning takes place. The synthesis does not, in any way, claim to be extensive. Instead it only concentrates on the 
pertinent literature that marks a promising shift in how teachers improve their professional learning in the South African reform era. The articles that were chosen for inclusion were read individually and summarised. In summarising the information, I read the introduction and focused on the purpose of this article, the findings and the discussion or conclusion. I used the summary notes to organise the themes that I had identified.

Three themes that are overlapping were identified: teacher professional development, teacher professional learning and the professional learning opportunities. The section on the theme of teacher professional development, which I present first in the review, encompasses how the concepts of "professional development" and "professional learning" are distinguished from each other. This is followed by the section that looks at the professional learning opportunities that brings about powerful teacher professional learning. Finally, the review considers what and how teachers learn from these professional learning opportunities.

\section{Discussion}

\subsection{Teacher "professional development" and "professional learning"}

There is a tendency in the literature to talk about "professional development" and "professional learning" as interchangeable terms. It turns out that there is a fine line that distinguishes the two concepts. Contrary to teacher professional development, which refers to activities that are aimed at bringing about changes in teacher practices, teacher professional learning implies an internal process of cognitive changes in teachers' thinking, knowing and doing (Knapp, 2003). Professional learning focuses on the state that is brought about by engaging in professional development activities. Professional development includes formal and structured experiences such as seminars as well as informal and unstructured ones, such as random discussions among colleagues about their work. Meanwhile, from a situative perspective, teacher learning is defined as "a process of increasing participation in the practice of teaching, and through this participation, a process of becoming knowledgeable in and about teaching" (Adler, 2000: 37). Teacher learning is what happens in teachers' different aspects of their practice such as in their own classrooms and teacher communities.

Teacher professional development is a target for every education reform, hence, the two are considered as one and the same (Sykes, 1996). It is not surprising that with the inception of education reforms in South Africa, major focus was placed on the professional development of its teachers. The bulk of literature on teacher professional development in the South African context uses various and wide-ranging terms to refer to this concept of teacher professional development. It is referred to as staff development, in-service education for teachers (INSET) and commonly, Continuous Professional Development for Teachers (CPTD). INSET/CPTD encompasses all those support professional development activities in which teachers engage following their initial teacher certification aimed primarily at improving their professional knowledge and teaching skills (Mutshekwane, 1994; Mestry, Hendricks \& Bischoff, 2009). Continuous professional development programmes were specifically designed for teachers to update their content knowledge and upgrade their teaching skills (Steyn, 2009)

Research on professional development indicates that teachers participate in professional development for various reasons. It may be for improving one's skills in performing their job, for career development or promotion purposes, to improve one's professional knowledge and understanding, for teachers' motivational purposes, or to help teachers prepare for transformation in education (Craft, 2000). It is noted in the South African literature that at the early stages of education reforms, the professional development offered to teachers was more related to school reform and transformation rather than to enhancing their professional knowledge (Reddy, 2005; Bantwini, 2009). Thus, professional development was aimed at promoting teachers' skills to fulfil the new agenda of transformation to reconstruct the education system (Mestry et al.,2009) rather than improving their content knowledge and teaching skills. Professional development was initially those one-shot, episodic workshop sessions rather than the programs provided over the extended period and that emphasize continual learning.

Another aspect that is noted in South African professional development literature is that in the beginning of the education reforms, the focus was more on understanding the professional development models and their elements which were targeted at developing teachers' content knowledge and teaching approaches (Steyn, 2008). The emphasis was more on the forms of teacher development rather than the process of change as teachers participate in these forms. For instance, the cascade workshop model (Mogari \& Onwu, 2004; Lessing \& de Witt, 2007; Le Roux, 2005), and schoolbased professional development (PD) models (Kriek\& Grayson, 2009; Bantwini, 2010) were different forms that teachers were part of. Previous professional development models focused primarily on the "what" question and often neglected the "how" question (Bryan, 2011). In other words, a large part of literature on professional development was concerned with the procedures and outcomes that only brought about slight changes in teachers' professional practice (Evans, 2002). 
For a long time, professional development was regarded as a traditional "training" model that emphasises the delivery of some kind of information to teachers rather than a process that supports the creation of the professional knowledge (Webster-Wright, 2010). Maistry, 2008, cites Kennedy (2005: 235) who views this "training model" for professional development as advancing a "skill-based, technocratic view of teaching". Eaton (2008:755) refers to this training approach as "factory-model type of education which regards teachers as factory workers who are instructed how to tighten a screw while the products roll by on the assembly line". Research indicates that during the introduction of the reforms in the South African context, traditional approaches to professional development such as workshops, courses and seminars and the common approach, the cascade model of teacher professional development were mostly used (Potenza \& Monyokolo, 1999; Kriek \& Grayson, 2009). Unfortunately, such a PD model had limited effectiveness for the professional learning of those South African teachers who were mostly affected by the legacy of apartheid education and thus had been exposed to inferior school and teacher education (Maistry, 2008: 67).

Generally, the focus of teacher professional learning is on the increase of professional knowledge and skills rather than the details of the activities in which teachers engage. Significant literature that focus on the process of teacher professional learning of teachers in South Africa emerged late in the last decade. A large part of this literature views teacher professional learning as a process of growing in the knowledge of teaching that happens through the participation in professional learning communities (Adler, 2000; Maistry, 2008b; Jita \& Ndlalane, 2009; Steyn, 2011). Steyn (2011) expands on this concept of teacher professional learning when she refers to it as continuous and lifelong learning where teachers develop a greater sense of collaboration to enhance teaching and learning in schools.

Researchers on professional development in the developed world have concurred about some of the elements of effective professional development associated with powerful effects on teacher professional learning (Hawley \& Valli, 1999; Wilson \& Berne, 1999; Garret, et al., 2001; Borko, 2004; Penuel, Fishman, Yamaguchi \& Gallagher, 2007). These features include extended duration, active learning, content focus, coherence and collective participation. The literature shows that some of the professional development models that were emphasised in South Africa had some of the elements that match the agreed-upon elements of the PD as mentioned above (Mogari \& Onwu, 2004; Kriek \& Grayson, 2009; Bantwini, 2009). However, their effectiveness was different in that the elements of some PD initiatives resulted in improving teacher classroom practice (Mogari \& Onwu, 2004) while others failed to do that (Bantwini, 2009). Unfortunately, mostly the professional development programmes tended to focus on the content or on the teaching techniques (Mundry, 2005) rather than on promoting teachers' subject knowledge and teaching skills. Recent literature starts to focus on the professional development that works (Mokhele \& Jita, 2012). This refers to the type that carries all the features of high-quality professional development and, furthermore, satisfies teachers' needs.

\subsection{Professional learning opportunities on teacher professional learning}

The literature alludes to formal learning opportunities and informal or on-the-job learning opportunities that occur in different venues (Paris \& Spillane, 2010). Most of the formal learning opportunities follow the traditional "training" approach, as already mentioned above. They usually occur outside the teaching context which is the classroom, and are often facilitated by an expert whose main aim is to teach the teachers. The informal learning opportunities usually take place within the teachers' workplaces where teachers actively engage in their learning. These involve instances in which teachers exchange ideas about their work, asking questions and getting answers, observing colleagues, sharing feedback and engaging in conversations with students and parents (Knapp, 2003).

Recent research throughout the world indicates a rapidly growing shift in professional development that considers the contexts in which teaching and learning takes place (Putnam \& Borko, 2000; Borko, 2004; Jita \& Ndlalane, 2009; Opfer \& Pedder, 2011; Steyn, 2013). Due to inadequate professional development that was not often successful in bringing about changes in teachers' practices, researchers started exploring other strategies that would change this situation. This is how alternative approaches to professional development that started to consider teachers' classrooms, schools and any context where teachers discuss their practice started gaining attention. Powerful forms of teacher learning emanated from affiliations in communities of practice that are outside teachers' classrooms or workplaces. These approaches bring to view the learning opportunities where teachers work in collaboration with each other, and in that way, learns from each other.

Due to the continuing ineffectiveness of numerous interventions in promoting teachers' professional growth, research work on the trend of context-based professional development started emerging in South Africa as well. Some scholars paid attention to the professional learning communities (PLCS), usually known as teacher clusters in South Africa (Jita \& Ndlalane, 2009; Jita \& Mokhele, 2013; Steyn, 2008; 2009), or communities of practice (Graven 2002; Maistry, 2007; 2008) mentoring (Ramnarain \& Ramaila, 2012) and study groups (Ono \& Ferreira, 2010; Posthuma, 2012). 
This current approach to professional learning is collaborative in nature and as such, carries a promising prospect for sustaining the momentum for change among teachers (Maistry, 2007). As teachers exchange ideas and share knowledge about their practice, they develop deeper understanding (Maistry, 2008).

Steyn (2011) highlights that previous literature on professional learning in South Africa concentrated on the professional learning of teachers as an individual process of constructing knowledge, in contrast to current literature that focuses on collaborative involvement in everyday school practices. As already mentioned, more emphasis was placed on professional learning opportunities and less on teachers' work environments. Evans (2002) refers to "functional development" when talking about professional learning opportunities that consider the context in which a teacher works and which encourages teachers to reflect on their practices. Bryan (2011) alludes to successful functional development in her case study that explored how the context in a South African rural school impacted on its teachers' attitudes and practice, that the school should strive to develop a collaborative learning culture that will enable teachers to gain an understanding of themselves within their working context as they reflect on their practice. Theorising teacher learning in terms of participating in collaborative communities is now a well-established trend in South Africa.

Maistry $(2007,2008)$ explored this collaborative nature of teacher professional learning through a community of practice for history teachers. Communities of practice initially referred to informal groups of teachers working together in interaction with others to improve their practices (Wenger, 1998). In such communities, teachers establish relationships, exchange information and provide support to each other. Research continued to recognise these professional learning communities as a way to promote teachers' growth in their knowledge and teaching practices (Ndlalane, 2006; Jita \& Ndlalane, 2009; Steyn, 2013). Researchers look at these communities of professional learning from different angles and sometimes they are interpreted differently in different contexts. Steyn (2013), for instance, pays attention to professional learning communities and the conditions such as the school environment and its leadership that enhance and sustain these collaborative structures of teacher learning. She concludes that both the individual and collective approach to teacher professional learning supported by conducive environments heightens the possibility for meaningful change among teachers. Other South African scholars often use the concept of "teacher clusters" to refer to these PLCs (Ndlalane, 2006; Jita \& Ndlalane, 2009; Jita \& Mokhele (2012). They direct our focus away from the structures of these communities to the reasons behind their existence and how they actualise those reasons. These researchers have proven that teachers who learn through participating in professional communities show improved learning. Maistry (2007) puts it well when he stated that teacher communities provide sites or locations for teacher professional learning.

\subsection{What and how do teachers learn from these professional learning communities?}

The works of the scholars mentioned in the section above (Maistry, 2007; 2008b; Jita \& Ndlalane 2009; Steyn 2013) further highlights that is not the existence of these communities that brings about professional learning but teacher collaborations and the conditions that encourage that collaboration. The teacher communities create the space for teachers to have a dialogue with colleagues within and outside their school about common issues in their subject and classroom practice. They exchange ideas and through that exchange, reach common understanding about issues that are relevant to them. It is a fact that teachers possess different strengths, knowledge and skills. Those at a higher level assist their colleagues through discussions and questions about their subject concepts (Jita \& Ndlalane, 2009). Teachers learn from one another and, in that way, enable each other to expand and develop their knowledge and teaching capabilities. In addition to how teachers learn, current literature also emphasises the conditions and strategies that are important to stimulate learning within the professional communities. Steyn (2013:285) advocates strategies such as clear vision to support professional learning communities, appropriate structures and processes for PLCs, scheduled time for PLCs, suitable facilitators, supportive leadership and follow-up. A powerful sense of commitment to their communities of learning and trust of support from peers is necessary for teachers to learn (Jita \& Ndlalane, 2009). Teachers should want to learn and not feel as if they are compelled, otherwise collaboration will not be a success.

\section{Conclusion}

A remarkable effort to enhance teacher professional learning in the South African context cannot be disputed. This is evident in the implementation of high-quality professional development initiatives and policy frameworks that stimulate such initiatives. Furthermore, better conceptualisation of teacher professional learning which moves the scholarship away from the emphasis on individual learning to collaborative learning contributes to maximising this effort. This synthesis highlighted significant literature that suggests that teacher professional development may not be enough, but teachers need to engage in professional learning to change and maximise their knowledge and skills. A general consensus that 
teachers acquire learning from their contexts and how that happens has been established. Nevertheless, there are conditions and support strategies that influence professional learning of teachers differently in different contexts. More research that provides more ideas on the roles that these conditions play in enabling or constraining professional learning is needed. The insight gained from this further research may be useful in giving future direction towards the design of professional learning opportunities that may be effective in various contexts.

\section{References}

Adler, J. (2000). Social practice theory and Mathematics teacher education: A conversation between theory and practice. Nordic Mathematics Education Journal, 8,3, 31-51.

Bantwini, B. D. (2009). District professional development models as a way to introduce primary school teachers to Natural Science curriculum reforms in one district in South Africa. Journal of Education for Teaching. 35,2, 162-189.

Bantwini, B. D. (2010). How teachers perceive the new curriculum reform: lessons from a School district in the Eastern Cape province, South Africa. International Journal of Educational Development. 30,1, 83-90.

Bantwini, B. D. (2011). District officials' assumptions about teacher learning and change: hindering factors to curriculum reform implementation in South Africa. International Journal of Education. 3, 1.

Botha, R.J. (2002). Outcomes-based education and educational reform in South Africa.International Journal of Leadership in Education, $5,4,361-371$.

Borko, H. (2004). Professional development and teacher learning: mapping the terrain. Educational Researcher. 33(8): 3-15.

Bryan, C. (2011). Professional development during a period of change: a small-scale case study exploring the effect of context on practice in a South African rural school. Professional Development in Education, 37,1, 131-141.

Craft, A.. (2000). Continuing professional development: A practical guide for teachers and schools. London: Routledge.Department of Education, (2002). Revised National Curriculum Statement: Overview. Pretoria, Department of Education.Department of Education, (2006). The National Policy Framework for Teacher Education and Development in South Africa. Pretoria, Department of Education.

Darling-Hammond, L. (1997). School reform at the crossroads: confronting the central issues of education. Educational Policy, 11,2, 151-166.

Desimone, L. M., Porter, A., Garret, M. S., Yoon, K. S., \& Birman, B. (2002). Effects of professional development on teachers' instruction: results from a 3-year longitudinal study. Educational Evaluation Analysis, 24,2, 81-112.

Easton, L. B. (2008). From professional development to professional learning. Phi Delta Kappan, 755-761.

Eraut, M.(2007). Learning from other people in the workplace. Oxford Review of Education. 33,4, 403-422.

Evans, L.(2002). What is teacher development? Oxford Review of Education. 28,1,123-137.

Garet, M. S., Porter, A. C, Desimone, L., Birman, B. F. \& Yoon, K. S. (2001). What makes professional development effective? Results from a national sample of teachers. American Educational Research Journal. 38,4,915-945.

Ghaye, T. (2011). Teaching and learning through reflective practice. A practical guide for positive action. Abingdon: David Fulton.

Graven, M. (2002). An investigation of Mathematics teachers learning in relation to preparation or curriculum change. D. Ed Thesis (unpublished). Johannesburg: University of Witwatersrand.

Harris, A., \& Muijs, D. (2005). Improving schools through teacher leadership. Milton Keynes:Open University Press.

Hawley, W. D., \& Valli, L. (1999). The essentials of effective professional development: a new consensus. In Linda Darling -Hammond \& Gary. Sykes, Teaching as the learning profession: handbook of policy and practice. San Francisco: Jossey-Bass.

Jita, L., \& Ndlalane, T. (2009). Teacher clusters in South Africa: opportunities and constraints for teacher development and change. Perspectives in Education ,27,1.

Jita, L. C., \& Mokhele, M. L. (2012). Institutionalising teacher clusters in South Africa: dilemmas and contradictions. Perspectives in Education, 30,2,1-11.

Kennedy, A. (2005). Models of continuing professional development: a framework for analysis. Journal of In-Service Education, 31,2, 235-250.

Knapp, M. S. (2003). Professional development as a policy pathway. Review of Research in Education. 27,109-157. American Educational Research Association.

Knight, P. (2002). A systematic approach to professional development: learning as practice. Teaching and Teacher Education. 18, 229241.

Kriek, J., \& Grayson, D. (2009). A holistic development model for South African Physical Science Teachers. South African Journal of Education, 29,2,185-203.

Lave, J., \& Wenger, E. (1991). Situated learning: legitimate peripheral participation: Cambridge: Cambridge University Press.

Lessing, A., \& De Witt, M. (2009). The value of continuous professional development: teachers' perceptions. South African Journal of Education. 27,1, 53-67.

Le Roux, C. (2005). Exploring educators' expectations and experiences of in-service education and training (INSET) as continuing professional development opportunities. Southern African of Environmental Education. 22.

Maistry, M. (2007). Building communities of practice for the continuing professional development of history teachers: insights from the TEMS project. New Contree, 54,53-71. 
Maistry, M. (2008a). Transcending traditional boundaries for teacher professional development: exploring a community of practice approach to CPD. Journal of Education, 43, 127-153.

Maistry, M. (2008b). Towards collaboration rather than cooperation for effective professional development in South Africa. Insights from social practice theory. Southern African Review of Education, 14,1-2,119-141.

Mestry, R., Bischoff, T., \& Hendricks, I.(2009). Perceptions of teachers on the benefits of teacher development programmes in one province of South Africa. South African Journal of Education, 29, 475-490.

Mulaudzi, N.O. (2009). Implementation of the South African National Curriculum: The Educators' Perspective. Deta 2009 Conference.

Mundry, S. (2005). Changing perspectives in professional development. Science Educator. 14,1, 9-15.

Mutshekwane, A. (2004). From INSET Centres to Multipurpose Education Centres: Experience From the Limpopo Province. Journal of In-Service Education, 30,1,9-28.

Ndlalane, C. (2006). Teacher clusters or networks as opportunities for learning about science content and pedagogical content knowledge. PhD dissertation. Pretoria. University of Pretoria.

Ono, Y., \& Ferreira, J. (2010). A case study of continuing teacher professional development through lesson study in South Africa. South African Journal of Education. 30,59-74.

Onwu, G.O.M., \& Mogari, D. (2004). Professional development for outcomes-based education curriculum implementation: The case of UNIVEMALASHI, South Africa. Journal of Education for Teaching, 10,2,161-177.

Opfer, V.D., \& Pedder, D.( 2011). Conceptualizing Teacher Professional Learning. Review of Educational Research, 81, 3, 376-407.

Parise, L.M., \& Spillane, J.P. (2010). Teacher learning and instructional change: How formal and on-the-job learning opportunities predict change in elementary school teachers' practice. The Elementary School Journal, 11,3.

Posthuma, A. B. (2012). Mathematics teachers' reflective practice within the context of adapted lesson study. Pythagoras. 33,3, 140.

Payne, C.M. (2008). So much reform, so little change - the persistence of failure in urban schools. Cambridge, MA: Harvard Education Press.

Penuel.W.R., Fishman, B., Yamaguchi, R., \& Gallagher, L.P. (2007). What makes professional development effective? Strategies that foster implementation. American Educational Research Journal. 44, 4, 921-958.

Potenza, E., \& Monyokolo, V. (1999). A destination without a map: premature implementation of Curriculum 2005. In Jansen, J \& Christie, P (eds). Changing curriculum: studies on outcomes-based education in South Africa. Kenwyn:Juta:231-245.

Ramnarain, U., \& Ramaila, S. (2012). Mentoring as a viable and sustainable form of professional development for Physical Science teachers. Education as Change. 16,5, 255-268.

Reddy, V. (2005). Performance scores in international Maths and Science Study reflective of South African inequalities. Available at http://www.hsrc.ac.za/ Media Release 232-phtml.

Putnam, R., \& Borko, H. (2000). What do new views and thinking have to say about research on teacher learning? Educational Researcher, 29,1, 4-15.

Sawyer, R.D. (2001). Teacher decision making as a fulcrum for teacher development: exploring structures for growth. Teacher Development 5,1, 39-58.

Shulman, L.S. (1986). Those who understand: knowledge growth in Teaching. Educational Researcher, 15, 4-14.

Shulman, L.S. (1987). Knowledge and teaching: foundations of the new reform. Harvard Educational Review, 57,1-22.

Smit, B. (2001). How primary teachers experience education policy and change in South Africa. Perspectives in Education, 19,3, 67-84.

Steyn, G.M. (2008). Continuing professional development for teachers in South Africa and social learning systems: conflicting conceptual frameworks of learning. Koers. 73,1,15-31.

Steyn, G.M. (2009). Effective implementation of continuing professional development for South African Teachers. Acta Academica, $41,2,256-279$.

Steyn, G.M. (2011). Implementing continuing professional teacher development:policy and practice. Acta Academica, 43,1,211-233.

Steyn, G.M. (2013). Building professional learning communities to enhance continuing professional development in South African schools. Anthropologist, 15,3,277-289.

Sykes, G. (1996). Reform of and as professional development. Phi Delta Kappan, 77, 465-467.

Villegas-Reimers, E. (2003). Teacher professional development: an international review of the literature. Paris: UNESCO International Institute for Educational Planning.

Webster-Wright, A. (2010). Authentic professional Learning. Dortecht:Springer.

Wilson, S. M., \& Berne, J. (1999). Teacher learning and the acquisition of professional knowledge: an examination of research on contemporary professional development. In A. Iran-Nejad \& PD. Pearson, Review of research in education 24, 173-209. Washington DC: American Educational Research Association. 